\title{
Порівняння гемостатичних засобів, що використовуються в хірургії
} Національний інститут раку, Київ

DOI: $10.32471 /$ clinicaloncology.2663-466X.39-3.27638

\begin{abstract}
Ефективний контроль кровотечі для досягнення гемостазу під час хірургічних процедур має важливе значення для досягнення позитивних результатів. Коли хірург досягає швидкого гемостазу, потенційними перевагами $є$ скорочення часу операції, зниження потреби в трансфузії, кращий супровід пацієнтів на антикоагулянтній терапії, пришвидшення загоєння післяопераційних ран та загальне полегшення реабілітаційного періоду. Використання гемостатичних агентів, герметиків та клеїв покращує гемостаз та дає ряд переваг під час хірургічного втручання. За останній час було розроблено широкий спектр хірургічних гемостатичних агентів для використання в хірургії. Ці агенти значно різняться за механізмом дії, складом, зручністю, можливістю використання на вологій або сухій тканині, імуногенністю та ціною. Численні формули цих агентів мають потенціал для точної відповідності конкретним хірургічним потребам. Необхідно обирати відповідні агенти для кожної конкретної ситуації в залежності від ефективності, ускладнень та ціни.
\end{abstract}

Ключові слова: велика рогата худоба; фібрин; фібриноген; гемостаз; герметик; тромбін; хірургія.

\section{ВстУП}

За останні 15 років було розроблено широкий спектр гемостатичних засобів для використання в хірургії. Ці засоби можна розділити на 3 великі категорії: гемостатики, герметики та клеї. Вони відрізняються за механізмом дії, складом, зручністю, можливістю використання на вологій та сухій тканинах, імуногенністю та ціною.

Ця стаття присвячена засобам, що використовуються в хірургії для досягнення гемостазу; засоби, що проходять клінічні випробування, також охоплено.

Коли хірурги досягають швидкого гемостазу, потенційними перевагами цього є краща візуалізація операційного поля, скорочення часу оперативного втручання, зменшення потреби у гемотрансфузії, краще ведення пацієнтів на антикоагулянтній терапії, пришвидшення загоєння післяопераційних ран та загальне полегшення реабілітаційного періоду. Потреба у безпечних та ефективних кровоспинних засобах, що можуть забезпечити ряд переваг, є важливим питанням у хірургії.

Ефективне управління кровотечею для досягнення гемостазу під час хірургічних процедур має важливе значення для отримання позитивних результатів [1]. Природній гемостаз людини забезпечує висококонтрольований процес, який підтримує кровотік, коли відбувається тромботична відповідь на ураження тканин, та включає комплексну взаємодію між коагуляцією та фібринолітичними факторами, тромбоцитами та стінкою судини. Гемостаз має 2 стадії: первинну клітинну стадію, яка ініціюється безпосередньо після ураження ендотелію та характеризується вазоконстрикцією, адгезією клітин запальної реакції та формуванням первинного вогкого агрегованого тромбу, шо складається з тромбоцитів та фібриногену, та другу гуморальну стадію, протягом якої цей м'який тромб стабілізується шляхом формування згустку, шо полегшується завдяки тромбоцитам, які підтримують вазоконстрикцію та зменшення кровотоку шляхом секреції тромбоксану та серотоніну. Коагуляційний каскад перетворює розчинний білок плазми фібриноген на нерозчинний фібрин через тромбін, одночасно з перетворенням фактору XIII на XIIIа, що ініціюе зшивання фібринових мономерів та призводить до утворення стабільного згустку [2, 3]. Ідеальний набір характеристик гемостазу має поєднувати біодеградацію з мінімальними побічними явищами та забезпечувати швидку реакцію після досягнення гемостазу, запобігаючи при цьому тромбозу.

Використання гемостатичних агентів, герметиків та клеїв покращує гемостаз та дає ряд переваг під час хірургічного втручання. Важливість гемостазу спонукала до подальшого пошуку нових агентів, серед них оксигенована відновлена целюлоза (oxidized regenerated cellulose - ORC), желатин свиней, колаген крупної рогатої худоби, полісахаридні сфери та тромбін [2]. За останній час було розроблено широкий спектр хірургічних гемостатичних агентів для використання в хірургії. Такі агенти можуть бути розділені на 3 категорії: гемостатики, герметики та клеї; ці широкі категорії також можна додатково розділити [2]. Як правило, гемостатики можуть бути розділені на наступні категорії: механічні, активні та текучі. Герметики можна поділити на фібринові та синтетичні. Клеї для хірургії класифікуються таким чином: ціанокрилати, альбумін та глутаральдегід (таблиця).

\section{ГЕМОСТАТИКИ}

Механічні. Механічні агенти (також називаються пасивними) вважаються найбільш ефективними для малих кровотеч та діють шляхом формування бар'єру, що швидко зупиняє потік крові та формує поверхню, яка сприяє більш швидкому згортанню крові. Механічні гемостатики використовуються в хірургії вже більше 50 років. На початку ХХ ст. гемостаз досягався механічними засобами, що включають затискачі, кліпси, шви, припікання та пряме стискання [2]. 31950 р. набули поширення електрокоагуляція, аргонова коагуляція [4] та лазери. Нещодавно набув поширення цілий ряд механічних агентів для хірургії, таких як желатин, колаген та ORC-матеріали.

Желатин. Желатин - це гідроколоїд, отриманий шляхом часткового кислотного гідролізу колагену свиней, який вспінюється та висушується. Він існує у формі губки та порошку та може використовуватися окремо та в комбінації з топічним тромбіном. Желатин абсорбує до 40 разів більший об'єм крові порівняно з його власним об'ємом та розширюється до $200 \%$ первинного розміру. Із сухої губки можна вирізати будь-який розмір та форму. Її можна наносити як у сухому вигляді, так i безпосередньо притискати на поверхню, що кровоточить для досягнення гемостазу. Після розгортання губку можна залишити на місці кровотечі, вона абсорбується протягом 4-6 тиж. Існує 2 добре відомих желатини (див. таблицю). Переваги желатинів наступні: відносно низька вартість, можливість зберігання за кімнатної температури та використання як основи для ORC. Однак існують деякі обмеження використання, наприклад можливість «перенапруження» при нанесенні на обмежених малих просторах, що може призвести до пошкоджень тканин. Із цієї причини желатини не використовуються інтраваскулярно. 
Таблиця 1. Класифікація гемостатичних засобів для використання в хірургії

\begin{tabular}{|c|c|c|c|}
\hline Група & Категорія & Клас & Бренд \\
\hline \multirow[t]{15}{*}{ Гемостатики } & \multirow[t]{9}{*}{ Механічні } & \multirow[t]{2}{*}{ Желатин свиней } & Gelfoam, губка та порошок (№ 1) \\
\hline & & & Surgifoam, губка та порошок (№ 2) \\
\hline & & \multirow[t]{4}{*}{ Колаген великої рогатої худоби } & Avitene (№ 3) \\
\hline & & & Ultrafoam (№ 4) \\
\hline & & & Helistat, Helitenelnstat \\
\hline & & & Instat MCH (№ 5) \\
\hline & & Карбоксиметилцелюлоза натрію & Алпе ГЕМОСТОП \\
\hline & & \multirow[t]{2}{*}{ Оксигенована відновлена целюлоза } & Surgicel (№ 6) \\
\hline & & & Surgicel Nu-Knit (№ 8) \\
\hline & \multirow[t]{4}{*}{ Активні } & Тромбін великої рогатої худоби & Thrombine JMI (№ 9) \\
\hline & & Тромбін з людської очищеної плазми & Evithrom (№ 10) \\
\hline & & & Gelfoam Plus (№ 11) \\
\hline & & Рекомбінантний людський тромбін (rh Тромбін) & Recothrom (№ 12) \\
\hline & \multirow[t]{2}{*}{ Текучі } & Желатин свиней+тромбін & SurgiFlo (№ 13) \\
\hline & & Желатин великої рогатої худоби та тромбін з людської очищеної плазми & FloSeal (№ 14) \\
\hline \multirow[t]{7}{*}{ Герметики } & \multirow[t]{3}{*}{ Фібринові } & Людська плазма та людський тромбін & Evicel (№ 15) \\
\hline & & Індивідуальний людська плазма, колаген та тромбін великої рогатої худоби & Vitagel (№ 17) \\
\hline & & Людська очищена плазма та колаген коней & Tachosil (№ 18) \\
\hline & \multirow[t]{4}{*}{ Синтетичні } & 2 ПЕГ & CoSeal (№ 19) \\
\hline & & ПЕГ, розчину арилцилінаміна та барвника FD\&C blue № 1 & DuraSeal (№ 20) \\
\hline & & & DuraSealXact (№ 21) \\
\hline & & ПЕГ та людський плазмовий альбумін & Progel (№ 22) \\
\hline \multirow[t]{2}{*}{ Клеї } & Ціанокрилат & Ціанокрилат з барвником FD\&C violet № 2 & Surgiseal (№ 23) \\
\hline & $\begin{array}{l}\text { Альбумін та глута- } \\
\text { ральдегід }\end{array}$ & Плазма великої рогатої худоби та 10\% глутаральдегід & Bioglue (№ 24) \\
\hline
\end{tabular}

Колаген. Колагеновий гемостатик отримують зі шкіри крупної рогатої худоби. Він має щільно прилягати до поверхні крові для забезпечення утворення матриці формування та зміцнення згортку, а також посилення агрегації тромбоцитів, дегрануляції та вивільнення факторів згортання крові, що призводить до формування тромбу. Він виявився ефективним для контролю артеріальних кровотеч у пацієнтів 3 низьким рівнем тромбоцитів. Цей гемостатик доступний у формі серветок та порошку, добре прилягає до неправильних поверхонь та готовий до використання з коробки. Хоча він є дорожчим за желатин свиней, гемостазу можна досягти за менший проміжок часу (1-5 хв). Його легко видалити з поверхні шляхом змивання та аспірації, що знижує ризик повторних кровотеч та потребу в повторному використанні. Залишений на місці, він абсорбується за 8-10 тиж. Проблеми, які можуть виникати у разі використання колагену крупної рогатої худоби, включають набрякання та алергічні реакції. Тому колагенові гемостатики не слід використовувати на ділянках, де вони можуть тиснути на оточуючі структури, або для закриття шкіри, що може погіршувати загоєння країв ран, а також у пацієнтів з алергічними реакціями або чутливістю до матеріалів, що виготовляються з матеріалів крупної рогатої худоби. Популярні колагени представлені в таблиці.

Оксигенована відновлена целюлоза. ORC-продукти отримують з рослинної альфа-целюлози. Вони доступні у формі тканини, що розсмоктується, одно- та багатошарової, яка може бути низької та високої щільності. ORC-продукти зберігаються за кімнатної температури, можуть використовуватися негайно та абсорбують до 7-10 разів більше власної маси. Вони діють на внутрішній шлях згортання, спричинюючи контактну активацію та активацію тромбоцитів та абсорбуючи, утворюється желатиноподібна маса, що сприяє утворенню згортку. Ці продукти використовують для контролю капілярної, венозної та артеріальної кровотечі та можуть бути розрізані на стрічки або менші шматочки для позиціювання. Вони мають бути нанесені сухими та абсорбуються протягом 4-8 тиж. ORCпродукти не варто використовувати в закритих просторах через можливість набрякання та для контролю кровотеч із крупних артерій. Існує декілька їх форм (див. таблицю). Бренди № 6 та № 8 суцільної волокнистої форми, у той час як бренд № 7 - у формі порожнистого волокна, однак механізм їх дії $є$ однаковим.
Карбоксиметилцелюлоза натрію. На ринку України представлений Алпе ГЕМОСТОП, що вже встиг себе зарекомендувати. Це стерильна гемостатична марля з карбоксиметилцелюлози натрію, що поєднує властивості місцевого гемостатика і герметика і використовується в ході різноманітних оперативних втручань. Гемостатична марля з карбоксиметилцелюлози при контакті з кров'ю швидко перетворюється на гель, блокує кровоносні капіляри і дрібні судини, підвищує в'язкість крові, активує агрегацію тромбоцитів і еритроцитів та сприяє полімеризації фібрину. Герметизація відбувається за рахунок утворення клейкого гелю, що забезпечує додаткове склеювання країв рани при їх зшиванні. Алпе Гемостоп у ході операції забезпечує хорошу адгезію до тканин, швидкий місцевий гемостаз (2-3 хв), герметизацію поверхні резекції та не потребує видалення після операції.

Завдяки декільком етапам хімічної модифікації рідка гемостатична марля з карбоксиметилцелюлози натрію має короткий срок біодеградації та повністю розсмоктується протягом 48 год на відміну від окисленої карбоксиметилцелюлози (період деградації - до 2 тиж), що мінімізує ризик виникнення інфекції. Гемостатичний матеріал з карбоксиметилцелюлози володіє хорошою біосумісністю і в порівнянні з продуктами 3 колагену і плазми крові людини сприяє адекватній імунній відповіді та нижчому ризику виникнення коагулопатій.

У дослідженні під час порівняння гемостатичної активності нових аплікаційних форм на основі карбоксиметилцелюлози саме зразок карбоксицелюлози натрію з коротким терміном біодеградації продемонстрував виражену гемостатичну активність у порівнянні з контролем і іншими матеріалами цієї групи, шо свідчить про його високу ефективність. Для досягнення ефективного гемостазу під час використання Алпе ГЕМОСТОП необхідно дотримуватися певних умов: не змочувати перед використанням, брати лише сухим інструментом, накладати безпосередньо на ділянку рани, не переміщувати по рані, оскільки матеріал швидко перетворюється на гель і це може призвести до незадовільного результату, у разі необхідності слід накласти декілька шарів, при використанні 3 профілактичною метою і за відсутності крові або ексудату необхідним є зволоження фізіологічним розчином для забезпечення адгезії. Досвід використання Алпе ГЕМОСТОП під час видалення пухлин різних локалізацій наведено на рис. 1-8.

Активні гемостатичні агенти містять тромбін - фермент, що каталізує перетворення фібриногену на фібрин у крові, 
останній крок у каскаді гемостазу. Наприкінці 1970-х років Управління з контролю за харчовими продуктами та лікарськими засобами США (Food and Drug Administration - FDA) схвалило топічний тромбін крупної рогатої худоби як засіб для досягнення гемостазу в хірургії [5]. Так, бренд № 9 (див. таблицю) - білкова речовина, яку отримують шляхом взаємодії тромбіну великої рогатої худоби та хлориду кальцію; він наноситься безпосередньо та поверхню, що кровоточить, для досягнення гемостазу. Від того часу тромбін отримували з різних джерел, у тому числі від крупної рогатої худоби, людський та рекомбінантний. Первинно використовували тромбін крупної рогатої худоби, але виникали ускладнення, пов'язані з утворенням антитіл, що вступали в перехресну реакцію з людськими факторами згортання. Людський тромбін, який виділяється з очищеної донорської плазми, було розроблено з метою мінімізації цих ризиків та зазвичай його використовують у комбінації з желатиновими губками. Однак доступність людського тромбіну обмежена, а також існує можливість передачі інфекцій гематогенним шляхом. Так, бренди № 10 та № 11 (див. таблицю) людського походження. Рекомбінантний людський тромбін (rhThrombin) було розроблено як синтетичний ресурс тромбіну без ризиків утворення антитіл, передачі патогенів крові та схвалено FDA у 2008 р. для широкого використання у хірургії людини. Бренди № 12 (див. таблицю) - це найбільш часто використовуваний гемостатичний агент, що містить рекомбінантний тромбін.

Текучі гемостатики. Категорію текучих гемостатиків можна розділити на 2 додаткових класи: продукти желатину свиней що комбінується з одним з 3 тромбінів (крупної рогатої худоби, людський або рекомбінований), та продукт колагену крупної рогатої худоби з тромбіном з людської очищеної плазми. Текучі гемостатики вважаються найбільш ефективними порівняно

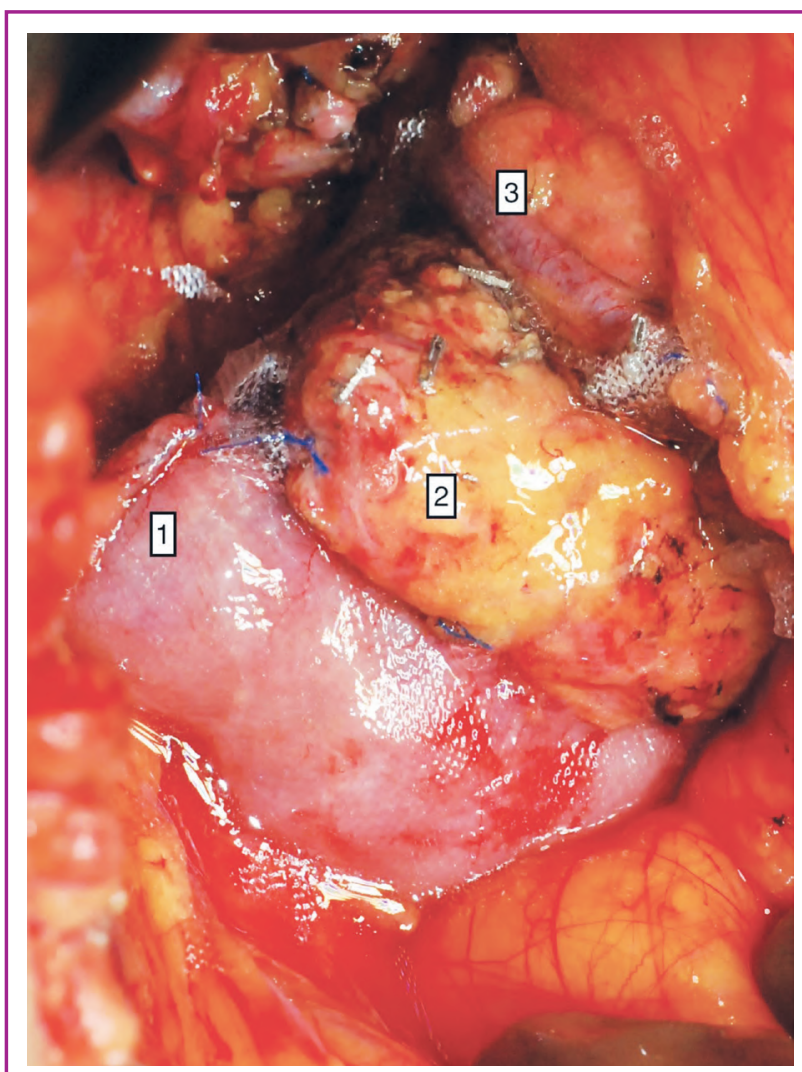

Рис. 1. Використання матеріалу Алпе ГЕМОстоП для запобігання післяопераційним кровотечам при резекції верхньої горизонтальної та нисхідної частин дванадцятипалої кишки із частковою неанатомічною резекцією підшлункової залози: 1 - кукса дванадцятипалої кишки; 2 - поверхня головки підшлункової залози; 3 - гастродуоденальна артерія

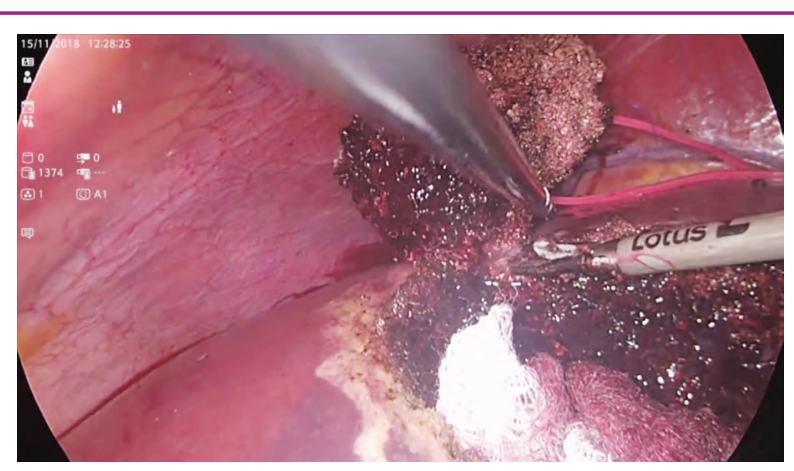

Рис. 2. Використання матеріалу Алпе ГЕМОСТОП при лапароскопічних резекціях печінки з приводу метастазів колоректального раку - етап операції з резекції печінки

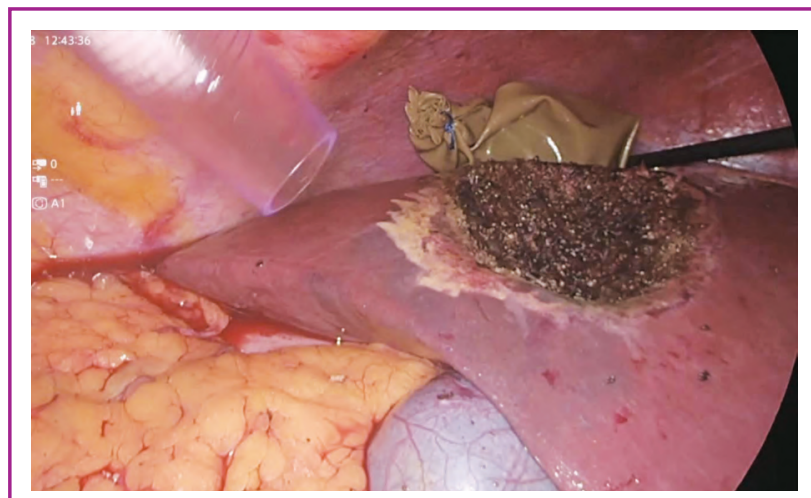

Рис. 3. Вигляд поверхні після резекції̈ печінки

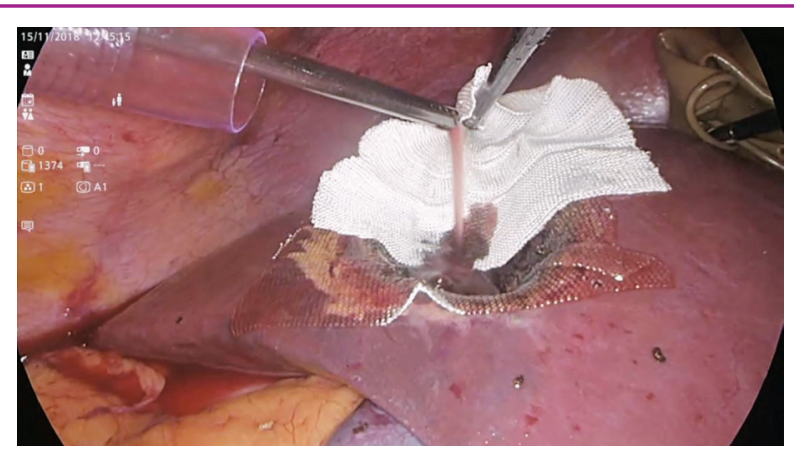

Рис. 4. «Закриття» поверхні резекціі матеріалом Алпе ГЕМОСТОП із додаванням фізіологічного розчину для покращення закріплення гемостатичного матеріалу

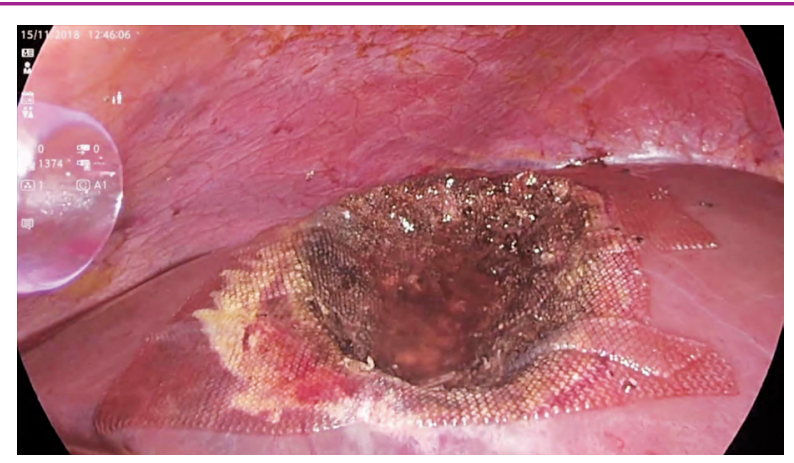

Рис. 5. Остаточний вигляд поверхні резекції після використання Алпе ГЕМОСТОП (дренування черевної порожнини не проводили, хворого виписано на 2-гу добу після операціi) 


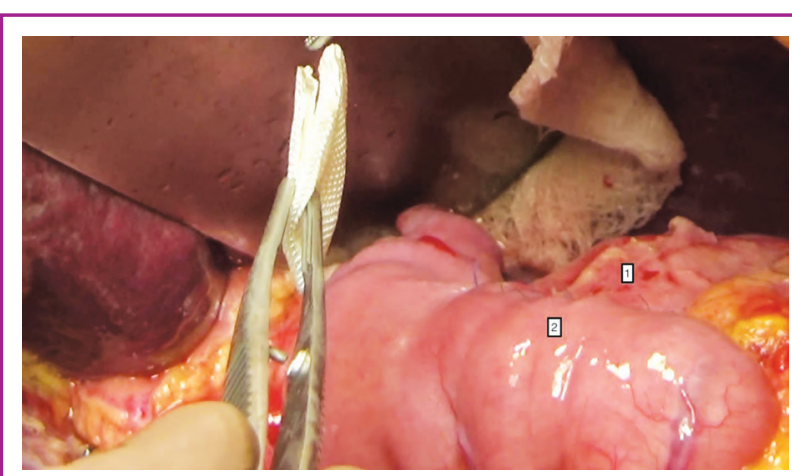

Рис. 6. Використання матеріалу Алпе ГЕМОСТОП при панкреатодуоденальній резекції з приводу раку підшлункової залози. Кінцевий вигляд панкреатоєюноанастомоз: 1 кукса підшлункової залози; 2 - анастомозована тонка кишка

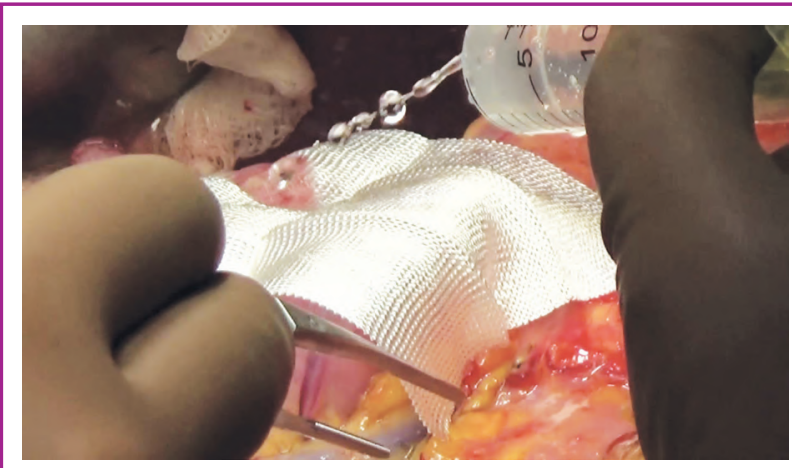

Рис. 7. «Закриття» поверхні панкреатоєюноанастомозу матеріалом Алпе ГЕМОСТОП із додаванням фізіологічного розчину для покращення закріплення гемостатичного матеріалу

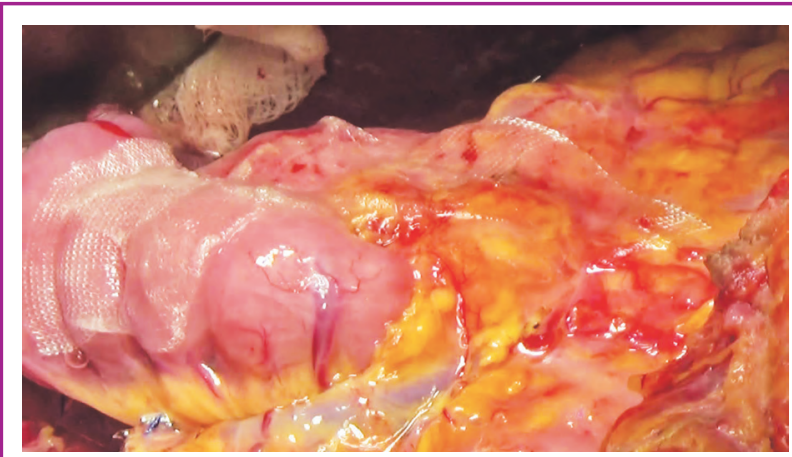

Рис. 8. Остаточний вигляд поверхні панкреатоєюноанастомозу після застосування Алпе ГЕМОСТОП, хворого виписано на 7-му добу без ознак панкреатичної фістули

3 іншими [2]. Серед них бренд № 13 (див. таблицю) - це стерильна та гемостатична матриця желатину свиней, що розсмоктується, поєднана з білковою речовиною, яку отримують шляхом взаємодії між тромбіном крупної рогатої худоби та хлориду кальцію, іiї наносять безпосередньо на сайт кровотечі для досягнення гемостазу. B.A. Woodworth та співавтори оцінили клінічну ефективність цієї матриці під час ендоскопічних операцій на синусі у 30 пацієнтів [6]. Було встановлено, що вказаний гемостатик був клінічно ефективним для зупинки кровотечі в 96,7\% випадків у пацієнтів протягом 10 хв після використання, побічних явищ не відмічалося (наприклад, інфекцій, адгезій або синехій). Його використовують під час кардіоваскулярних втручань для герметизації анастомозів.
Цей текучий гемостатик складається 3 желатинового матриксу, хлориду кальцію та людського тромбіну. Під час нанесення на поверхневу рану або хірургічний сайт желатинові гранули абсорбують кров та набрякають (20\% за 10 хв) та тампонують рану завдяки відповідності іїі геометрії. Висока концентрація тромбіну слугує для швидкої реакції з фібриногеном пацієнта для формування механічно стабільного тромбу, який реабсорбується протягом 6-8 тиж. Особливістю цього бренда є необхідність наявності крові для активації [7]. Також він потенційно може спричиняти тромботичні ускладнення при безпосередньому введенні у великі судини [8].

Було проведено ряд досліджень: дослідження шведських учених 2000 р., проспективне рандомізоване дослідження, виконане в Італії 2009 р., та додаткове для порівняння ефективності брендів № 13 та № 11. 309 пацієнтів з патологією з боку серця або спінальними проблемами було спеціально відібрано, оскільки місця кровотечі у них не були б легко доступними для інших кровоспинних агентів. У дослідженні було включено 93 пацієнти з серцевою патологією, 3 них 48 лікували з використанням бренда № 13 (у деяких пацієнтів було декілька місць кровотечі). Показано, що гемостаз протягом 10 хв був значно крашим у групі цього гемостатика: 92/104 (88\%) у порівнянні з 35/61 (57\%) у групі бренда № 11. У місцях з великою кровотечею вказаний текучий гемостатик продемонстрував кращі показники у порівнянні з продуктом порівняння. Повний гемостаз відмічено у $94 \%$ пацієнтів групи бренда № 13 порівняно з 66\% у групі бренда № 11 Хірурги робили оцінку, зважаючи на легкість у використанні обох продуктів та дійшли висновку, що нанесення на кровоточиву поверхню було легшим, а конформація до тканин була кращою у текучого гемостатика [8-10].

\section{ГЕРМЕТИКИ}

Фібринові герметики. Фібринові герметики також називають фібриновими клеями. Їх отримують з людських та/або тваринних продуктів крові, які імітують фінальні стадії гемостатичного каскаду у формуванні фібринового згустку. Комбінація ліофілізованих білків згортання (первинний фібриноген) та тромбіну містяться в окремих флаконах та взаємодіють під час нанесення з формуванням стабільного згустку. Підготовка та нанесення фібринового клею є дещо складними; фібриноген має бути розчинений у стерильній воді, тоді як тромбін - у розведеному розчині $\mathrm{CaCl}_{2}$. Згодом 2 розчини завантажують у шприц 3 двома резервуарами, що полегшує ïх нанесення. Деякі герметики містять 2 додаткових інгредієнти: людський фактор згортання XII, який зміцнює тромби, та апротинін, що отримують з легень великої рогатої худоби, який інгібує ферменти, що розчинюють тромби.

Фібринові герметики були доступні в Японії та Західній Європі з 1980-х років, але не були схвалені FDA для використання в США до 1998 р. За результатами кількох досліджень повідомляли, що фібринові герметики покращують результати хірургічного втручання, зокрема: скорочення часу операції, зниження рівня інфекційних та інших ускладнень, а також зменшення крововтрати [3, 11-13]. Фібринові герметики гарний вибір для судинної хірургії, що забезпечує ефективну герметизацію анастомозів до зняття судинних затискачів та відновлення тиску крові. Їх використовують переважно для додаткового гемостазу в різних ситуаціях, у тому числі у разі серцево-судинних операцій та втручань на аорті, каротидних ендартеректомій [14].

Бренд № 15 (див. таблицю) - це фібриновий герметик, який отримують 3 цільної людської плазми крові та випускають в упаковці з 2 різних флаконів фібриногену та людського тромбіну відповідно. Активні інгредієнти виділяють з цільної людської плазми. Два заморожені розчини мають бути розморожені перед використанням. Після відтавання та нагрівання до $20-30{ }^{\circ} \mathrm{C}$ два розчини змішують. У 2007 р. FDA розширило 
показання цього герметика для використання у судинній хірургії.

Бренд № 16 (див. таблицю) - це, певно, один 3 найвідоміших фібринових герметиків. Він складається з людського фібриногену та тромбіну, містить апротинін та хлорид кальцію. Апротинін - плазмовий інгібітор оксидаз, що перешкоджає деградації фібриногену та стабілізує сформований фібриновий згусток. Однак він є потенційним алергеном за рахунок чужорідного білка, отриманого з легень великої рогатої худоби. Також є дані про алергічні реакції та рідкісний випадок тяжкої реакції негайного типу, що наближався до летального, реакція була в першу чергу з кількома експозиціями [15].

Цей фібриновий герметик переважно використовується при серцево-легеневих операціях, невідкладних втручаннях на висхідній аорті, таких як переміщення висхідної частини аорти [16], серцево-легеневому шунтуванні [17] та протезуванні висхідної аорти [18]. Його не використовують на кровоточивих (вологих) ранах. Кровотеча має бути зупинена шляхом накладання зажиму проксимально, кров слід видалити, а тканини (судини) очистити та висушити перед нанесенням герметика. Має пройти 2-3 хв для висихання та полімеризації перед відновленням кровотоку.

J. Lowe та ін. лікували 317 пацієнтів, які брали участь у III фазі проспективного рандомізованого подвійного сліпого мультицентрового дослідження та перенесли кардіохірургічні втручання. Бренд № 16 VH або бренд № 16 VH (S/D) розчинник/детергент використовували на визначеному хірургом місці кровотечі та порівнювали. Бренд № 16 VH S/D було розроблено як наступне покоління фібринових герметиків у замороженому готовому до використання вигляді з додаванням етапом інактивації вірусу (S/D лікування) для гарантування безпеки та зручності використання. Встановлено, що нове покоління VH S/D було принаймні таким же ефективним, як VH; відсоток пацієнтів, у яких досягнуто стійкого гемостазу в первинному сайті (визначеному як місце середньої кровотечі) до хірургічного закриття становив 89,6\% з брендом № $16 \mathrm{VH}$ та 88,2\% з брендом № 16 VH S/D. Але останній мав дещо вищий рівень для сайтів незначної або мінімальної кровотечі у порівнянні з брендом № 16 VH з успішним гемостазом 95,1 проти 94\% відповідно [17].

У групі з 38 дітей з вродженими вадами серця бренд № 16 показав відмінні результати гемостазу у 31 пацієнта, хороший гемостаз у 6 та поганий лише в 1 пацієнта [19]. У національному дослідженні за участю 140 пацієнтів, які потребували артеріоартеріального або артеріовенозного шунтування в групі, у якій було використано цей фібриновий герметик, у 62,9\% випадків досягнуто гемостазу порівняно з ручним стисканням з ефективністю лише у $31,4 \%$ випадків. Не відмічалося жодних побічних ефектів під час використання вказаного герметика [20].

J. A. Rousou провів детальне вивчення літератури щодо фібринових герметиків з 1979 до 2012 р. та встановив, що бренд № 16 є найбільш вивченим. Було продемонстровано, що цей та інші фібринові герметики добре переносяться та забезпечують ефективний гемостаз для серцево-судинної хірургії (наприклад аортокоронарне шунтування, заміна серцевих клапанів, виправлення дефектів шлуночкових перегородок, лікування септичних ендокардитів, хірургія аорти). Основні переваги включали швидке досягнення гемостазу, зниження крововтрати та зменшення кількості повторних втручань [14].

Бренд № 17 (див. таблицю) складається з мікрофібрилярного колагену з тромбіном, фібриногеном та тромбоцитів. Цей герметик використовує власну плазму пацієнта, що виключає ризик передачі інфекцій цільної людської плазми. Його розроблено для безпечного та ефективного досягнення гемостазу шляхом формування тривимірного каркасу з колагену та фібрину, поєднаних з активованими тромбоцитами.

Бренд № 18 (див. таблицю) було схвалено для використання тільки у дорослих лише у 2010 р. [21]. Це двошаровий губчастий матеріал, що з одного боку складається з колагену коней, а з іншого - $з$ людського фібриногену та тромбіну. Колаген лягає на рану, тоді як фібриноген та тромбін слугують для завершення нормального коагуляційного каскаду [22].

При порівнянні стандартного гемостатичного волокна та бренда № 18 останній добре себе показав у дослідженні за участю 119 пацієнтів, при кровотечах з аорти (56\%), правого шлуночка (16\%), правого передсердя (13\%) та артеріальних судин (74\%). У 59 пацієнтів зупиняли кровотечі з використанням бренда № 18, у той час як у інших використовували гемостатичне волокно. Відмічено, що за допомогою бренда № 18 повного гемостазу досягали за 3 хв у 75\% пацієнтів порівняно з 33\% контрольної групи. 3 пацієнти контрольної групи потребували використання цього фібринового герметика для контролю кровотечі. Побічні ефекти були схожими в обох групах [23]. Фібриновий клей бренда № 18 також виявися ефективним у пацієнтів з гострим інфарктом міокарда що потребували коронарного шунтування [24].

У порівнянні з Gore-Tex, неадгезивною та нетромбогенвмісною речовиною, було відмічено значно менше спайок у групі бренда № 18 за винятком коронарної артерії, де майже не було відмінностей. На додаток, останній запобігав утворенню загрудинних спайок на відміну від використання нетромбогенвмісної речовини та нелікованої групи контролю. Не було значних відмінностей в рівні адгезії між групою, у якій використовували неадгезивну нетромбогенвмісну речовину, та контрольною [25].

Bolheal - це розчин фібринового герметика, що складається з 2 розчинів (А та В), які зберігаються окремо як заморожені рідини або можуть зберігатися охолодженими в формі рідини до 30 днів після розмороження тим самим запобігаючи втраті невикористаного продукту. Розчин А містить 80 мг/мл людського фібриногену, 75 Од/мл людського плазмового фактора згортання крові XIII та 1000 KIE апротиніну великої рогатої худоби, тоді як розчин В містить 250 Од/мл людського тромбіну та 5,9 мг/мл хлориду кальцію. У клінічній практиці розчин А та В змішуються у пропорції 1:1 об’єму. Під час змішування ці агенти імітують останню стадію каскаду згортання та формують фібриновий згорток. 20 пацієнтів, що перенесли ургентне протезування висхідної аорти та висхідного напівкола аорти, було розділено на 2 групи в рандомізованому порівняльному дослідженні. 10 пацієнтів (група G) лікували за допомогою методики втирання та розпилення, тоді як інші 10 учасників (група С) не отримували жодної терапії. Метод втирання та розпилення включав використання пальця для втирання розчину фібриногену в отвір голки та подальше розпилення над ділянками. Методика втирання та розпилення з використанням вказаного розчину фібринового герметика для групи G продемонструвала значну гемостатичну ефективність у порівнянні з групою С. Загалом з 55 отворів голок кровотеча відмічалася у 4,8\% для групи G і у 72,8\% у групі С, крововтрата до досягнення гемостазу становила - 99 мл для групи G у порівнянні з 257 мл для групи С та післяопераційна крововтрата понад 12 год - 268 мл для групи G та 526 мл - для групи С [3]. Хоча цей герметик доступний у Японіі, його не схвалено FDA для використання в США.

Фібриновий герметик Grifols складається з замороженого розчину людського фібриногену та людського тромбіну у комбінації з хлоридом кальцію. За даними проведеного рандомізованого дослідження, досягнення гемостазу у разі використання цього герметика менше ніж за 3 хв спостерігалося у 46,4\% випадків, тоді як при ручному стисненні - лише у 26,3\% [26].

CryoSeal був першим герметиком, який виготовляли з одної одиниці людської плазми. Це виключало ризики, асоційовані з використанням об’єднаних продуктів плазми. Його компоненти на 100\% виготовлені з людських матеріалів (кріопреципітат та тромбін), він не містить продуктів синтетичного або тваринного походження. Цей герметик виготовляють зі свіжозамороженої плазми, що пройшла карантин, від одно- 
го добровільного здорового донора. В останніх доповідях $\mathrm{S}$. Hazelaar та співавтори дійшли висновку, що походження від одного донора та відсутність фібринолітичних інгібіторів робить цей герметик гарною альтернативою мультидонорним та аутологічним фібриновим герметикам [27].

У мультицентровому рандомізованому дослідженні, у яке ввійшли 153 пацієнти, яким було проведено елективні резекції печінки, ефективність вказаного вище герметика для досягнення гемостазу була підтверджена. У цих випадках рівень фібринолітичного фактора плазміногену, який було заявлено для зниження потенційної вірусної трансмісії у порівнянні з об'єднаними продуктами [28], був у 3 рази вищим порівняно 3 брендом № 16, 360 мг/мл проти 20-120 мг/мл відповідно.

CryoSeal містить вищий рівень плазміногену (107 мг/мл), ніж бренд № 16 (40-120 мг/мл) [28], що дозволяє згусткам деградувати швидше, ніж у разі використання бренда № 16, коли плазміноген конвертується у плазмін, та дає ферментам можливість розчиняти згусток. Це є перевагою в обмеженні розповсюдження згустку, який може призвести до пошкоджень, якщо стане завеликим.

Синтетичні герметики. Синтетичні герметики складаються з поліетиленгліколю (ПЕГ) та як мінімум одного додаткового компонента. Це біодеградуючі агенти, що зазвичай діють як бар'єр для рідини та гемостатичний агент. Вони швидко утворюють клей та розсмоктуються за 1-6 тиж. Синтетичні герметики можуть бути дорожчими за інші агенти

Бренд № 19 (див. таблицю) - це хірургічний герметик, що позбавлений будь-якого людського або тваринного матеріалу. Він складається лише з двох ПЕГ: розведеного розчину натрію хлориду та фосфату натрію/розчину карбонату [29]. ПЕГ доступний у широкому діапазоні молекулярної маси (наприклад 300-10 000000 г/моль), пропорційно полімеризації етиленоксиду. Під час застосування комбінація цих розчинів формує гідрогель, який поєднується з білками для утворення спонтанного зв'язку з тканиною. Герметик повністю абсорбується протягом 30 днів після нанесення [30].

Дослідження, до якого було залучено 12 собак, які перенесли протезування здухвинної кістки політетраетиленовим протезом, для визначення ефективності вказаного синтетичного герметика як гемостатичного агента продемонструвало явні переваги. На одному кінці протезу використовували бренд № 19, а на іншому - притискання марлі. Були очевидними переваги використання герметика; час до досягнення гемостазу становив 5 хв порівняно 315 хв у контрольній групі. Крововтрата була меншою на кінці, лікованому з використанням синтетичного герметика (19 г проти 284 г на контрольному кінці). Герметик був ще помітним протягом 7 днів після операції та середній рівень запалення відмічали на 7-, 30- та 60-й дні [31].

У Німеччині 124 пацієнтам було проведено втручання на аорті 6 хірургами. Троє хірургів використовували бренд № 19, тоді як інші - ні. Хірургічні операції на аорті включали повну заміну цибулини аорти, реконструкцію або повну заміну висхідної аорти та втручання на напівколах аорти. Синтетичний герметик з 2 ПЕГ розпилювали на лінію шва та давали висохнути. Було продемонстровано, що група, у якій використовували вказаний герметик, потребувала меншої кількості трансфузії (наприклад еритроцитарної маси: 761 проти 1248 у контрольній групі; свіжозамороженої маси: 413 проти 779 в контрольній групі; також знижено рівень післяопераційної втрати по дренажах: 985 мл в групі бренда № 19 проти 1709 мл в контрольній групі). На додаток, менша кількість пацієнтів у групі герметика потребували рестернотомії (1 з 48 проти 6 з 54 в групі контролю) та для них було відмічено меншу кількість часу, проведеного в умовах інтенсивної терапії. Автори зробили висновок, що бренд № 19 продемонстрував себе як добрий гемостатичний агент, що зекономив 1943 евро на пацієнта [32].
Бренд № 20 (див. таблицю) - це герметик, що складається з розчинів складного ефіру ПЕГ й арилцилінаміну та барвника FD\&C blue № 1. Це запатентований синтетичний гідрогель, що розсмоктується, доступний у формі подвійного аплікатора шприца, може зберігатися при кімнатній температурі, час його підготовки становить менше 2 хв. При змішуванні під час розприскування попередники негайно зв'язуються з утворенням гідрогелевого герметика. Синій барвник забезпечує хірургам гарну візуалізацію покриття та товщини матеріалу під час нанесення. У післяопераційний період цей герметик продовжує герметизувати лінію шва, процес загоєння проходить під шаром гелю. Після кількох тижнів гідрогель руйнується до водорозчинних молекул, що абсорбуються та виводяться нирками.

Уперше його почали використовувати в нейрохірургіï. Коли його розпилюють на тверду мозкову оболонку, він має достатню силу адгезії до тканин та міцність, здатну протистояти цереброспінальній рідині. У дослідженні, презентованому K. Nashimura та співавторами в 2012 р., вказаний синтетичний герметик було досліджено на предмет можливості використання під час накладання анастомозу між поверхневою скроневою та середньомозковою артеріями, що є типовою процедурою для лікування церебральної ішемії, церебральних аневризм та пухлин. У когорті з 42 пацієнтів він створив водонепроникне закриття твердої мозкової оболонки легко та безпечно, навіть незважаючи на шунтуючі операції [33].

Нещодавно, бренд № 20 було відзначено знаком Conformite Europeennee (CE), що дозволяє його використання в Європі для герметизації шовних ліній як додаткового методу для стандартних технік закриття під час артеріальних та венозних реконструкцій у судинній хірургії [34] та під час елективних резекцій легень для герметизації вісцеральної плеври [35].

Бренд № 22 (див. таблицю) - це герметик, синтезований для герметизації плевральних втрат повітря після операції.

У ретроспективному дослідженні за участю одного хірурга було показано, що 75 пацієнтів зі 121 (57,9\%) мали проблеми з інтраопераційною втратою повітря (ІВП). Із 75 пацієнтів з ІВП 36 лікували з використанням бренда № 22 додатково до основного плеврального герметика. 34 пацієнти отримали лише плевральний герметик. Бренд № 22 продемонстрував кращий контроль над втратою повітря порівняно з контрольною групою. Після його використання лише у $11 \%$ пацієнтів відмічали подальші проблеми з ІВП, тоді як в контрольній групі у $56,8 \%$ хворих вони періодично з'являлися знову. Потреба в дренажі плевральної порожнини була менш тривалою в групі бренда № 22 (1 день порівняно з 2,5) та перебування у лікарні скоротилося вдвічі - 1,5 дня було необхідно для групи синтетичного герметика проти 3 днів у контрольній групі [36].

\section{КЛЕї}

Клейові гемостатики містять різні складові та використовуються переважно як додаткові методи, переважно у серцевосудинній хірургіi.

Ціанокрилат. Ціанокрилат міститься у таких продуктах, як Super Glue та Crazy Glue. На відміну від більшості агентів, під час використання яких слід видалити рідину з поверхні, ціанокрилати потребують невеликої кількості вологи для адгезії. До недавнього часу їх можна було використовувати лише зовнішньо у зв'язку з інтенсивною запальною відповіддю при контакті з іншими поверхнями. В основному ціанокрилати $€$ актуальними для закриття шкірних розрізів. Ціанокрилатні клеї використовувалися для лікування варикозу понад 20 років, уперше - шляхом ендоскопічного внутрішньовенного введення при пептичному варикозі [37], але внутрішньовенне використання ціанокрилатів для стволової абляції - це нещодавня розробка, яка тестується на свинях [38].

Альбумін та глутаральдегід. Альбумін та глутаральдегідний клей використовуються як додатковий метод для досягнення гемостазу великих судин. Вони відмінно з'єднуються з тканинами за 2-3 хв. Їх використовували при комплексних 
кардіальних втручаннях, таких як операції на розшаровуючих аневризмах аорти для покращення склеювання розслоєних стінок аорти. Бренд № 24 (див. таблицю) - найбільш часто використовуваний клей у судинній хірургії.

У 2001 р. за результатами дослідження, у якому порівнювали переваги гемостазу, досягнутого за допомогою бренда № 24, 3 такими бренда № 6, було зроблено загальний висновок, що бренд № 24 може мати переваги у пацієнтів з коагулопатією, які підлягають судинним втручанням. У цьому дослідженні процедури шунтування було проведено на низхідній грудній аорті після введення тваринам гепарину та ацетилсаліцилової кислоти. Клей продемонстрував вищу ефективність у попередженні крововтрати порівняно з вказаним механічним гемостатиком при негайному післяопераційному введені (470 проти 995 мл) та зменшив загальну крововтрату (668 порівняно з 1497 мл). Після 3 міс у овець, у яких використовували клей з альбуміном та глутаральдегідом, відмічалася мінімальна запальна відповідь [39].

Розрив вільної стінки після інфаркту міокарда призводить до просочування в перикард або гострого розриву. У одному дослідженні було проаналізовано досвід лікування 9 пацієнтів з інфарктом міокарда, які надійшли до відділення невідкладної допомоги з болем та тампонадою перикарду. Час, що пройшов між інфарктом міокарда та розривом вільної стінки, становив 122 год. У всіх 9 пацієнтів зону некрозу та перикардіальної гематоми було добре видно. Усі гематоми були розташовані у лівому шлуночку, хоч і в різних місцях. Хірург накладав Teflon на всю уражену ділянку та далі покривав клеєм з кальбуміну та глутаральдегіду. Не було відмічено післяопераційної смертності протягом 30 днів та у всіх пацієнтів збережено функцію лівого шлуночка без обмеження руху [40].

J. Passage та співавтори в 2002 р. провели комплексне дослідження, у ході якого 115 пацієнтів 3 широким діапазоном серцево-судинних захворювань отримували лікування, після чого було проведено аналіз результатів. Найчастіше у них відмічали аневризму аорти - 39 випадків та розшарування аорти - 30. Втручання включали, але не обмежувалися відновленням цибулини аорти та стінки аорти. Клей з альбуміну та глутаральлегіду було використано для досягнення гемостазу у 79 випадках, для з'єднання тканин - у 21 випадку та укріплення тканин - у 30. Було зроблено висновок, що бренд № $24 є$ дуже ефективним у разі використання під час таких процедур. Він показав себе як надійний та універсальний продукт з коротким часом забезпечення гемостазу, що добре зв'язується з навколишніми тканинами [41].

Однією з функцій біологічних клеїв є полегшення з'єднання окремих тканин, зокрема при розшаровуючій аневризмі. У таких випадках клей з альбуміну та глутаральлегіду обережно наносять між двома шарами, а псевдоотвір закривають [42]. Клей може бути досить ефективним у відновленні розшаровуючої аневризми, але не без ризиків. Як повідомляв A. Modi та співавтори, у 57-річного чоловіка, який отримував терапію з приводу розшаровуючої аневризми з використанням клею з альбуміну та глутаральлегіду, не відмічали проблем під час лікування, але він повернувся до відділення невідкладної допомоги 3 міс потому з нестабільною стенокардією, а ангіограма показала тяжкий мітральний стеноз. Було зроблено висновок, що клей витік з аорти до мітрального отвору та спричинив запальну відповідь у зв'язку з вмістом глутаральдегіду, що спричинило фіброз та стеноз [43].

Використання бренда № 24 не рекомендується в педіатричній практиці, тому що глутаральдегід у комбінації з плазмовим альбуміном великої рогатої худоби утворює нееластичне ущільнення. Десяти малюкам віком 4 тиж було накладено первинний аортальний анастомоз, у 5 його укріплювали за допомогою клею та через 7 тиж порівнювали просвіт аорти.

У тварин, яких лікували з використанням бренда № 24 , діаметр просвіту аорти становив 1,5 см у порівнянні з контрольною групою, діаметр аорти у яких $-2,7$ см $(\mathrm{p}=0,054)$. На до- даток у всіх тварин, які отримували терапію з використанням клею, відмічали фіброз, водночас жодного такого випадку не відмічено в групі контролю $(\mathrm{p}=0,008)$ [44]. Автори зробили висновок, що укріплення судинних анастомозів за допомогою клею з альбуміну та глутаральдегіду спричиняє фіброз аортальних анастомозів.

\section{ВИСНОВКИ}

Оскільки методи проведення хірургічних втручань розвиваються, стають досконалішими та менш інвазивними, використання швидкодіючих біологічних та синтетичних гемостатиків, що включають фібринові герметики, рідкі желатини та адгезиви, набуває все більшого розповсюдження. Численні формули цих агентів потенційно можуть точно відповідати конкретним хірургічним потребам.

Необхідні подальші дослідження для вивчення ефективності локального використання гемостатиків у пацієнтів, яким проводять хірургічні втручання, особливо тих, хто з приводу серцево-судинних хвороб отримує незворотний антиагрегант клопідогрель або ацетилсаліцилову кислоту для встановлення доцільності їх використання в даних ситуаціях $[45,46]$.

\section{ДУМКА ЕКСПЕРТІВ}

Топічні гемостатичні агенти використовувалися хірургами для досягнення контролю над кровотечею впродовж багатьох років. Наразі доступні гемостатичні агенти з комбінованим хімічним складом. Тип їх дії варіює залежно від складу. Загалом ефективність гемостатиків є вищою, ніж ручне стискання. Кожний із цих продуктів може спричиняти ускладнення, навіть якщо частота їх невисока. Вартість варіює від 15 дол США до 650 дол.

Належне використання цих продуктів потребує глибоких знань їх складу та типу дії. Алпе ГЕМОСТОП створює матрикс для нормального згортання та герметизації анастомозів, що дає можливість попереджати ускладнення в ході оперативного втручання. Матеріал з карбоксиметилцелюлози натрію 3 швидкою біодеградацією розсмоктується за 2-3 дні, обумовлює бактеріостатичний ефект, шо перешкоджає інфікуванню і сприяє загоєнню.

Активні агенти, такі як тромбін, забезпечують гемостаз шляхом стимулювання коагуляції. Тромбін отримують з різних матеріалів: велика рогата худоба, рекомбінантні та плазмові білки людини. Також гемостатичні засоби виготовляють з людського фібриногену та тромбіну з апротиніном та хлоридом кальцію. Апротинін перешкоджає деградації фібрину. У ІІІ фазі клінічних випробувань цього продукту ми спостерігали гемостаз на рівні $62,9 \%$ порівняно з ручним стисканням, що продемонструвало ефективність лише $31,4 \%$.

Кожний із цих продуктів може нести ризики або викликати ускладнення. Тромбін великої рогатої худоби, як повідомлялося, міг спричиняти імуноопосередковану коагулопатію та рідко - анафілактичний шок [47]. Людський тромбін міг обумовлювати трансмісію вірусів, особливо у разі виробництва 3 цільної плазми, хоча наразі відмічається значне покращення очищення цих продуктів, що призводить до зниження рівня вірусної трансмісії. Це фібринові герметики, які отримують з однієї одиниці людської плазми.

Синтетичні гемостатики є також ефективними, проте досить дороговартісними. Ці продукти мають використовуватися у відповідних ситуаціях. Існує багато гемостатичних пов'язок для використання у разі великої поверхні кровотечі, коли ушивання є недоцільним. Багато 3 них рекомендовані з досвіду військових хірургів [48].

Гемостатичні агенти не замінять гарної хірургічної техніки. Їх первинна роль - додатковий засіб у хірургічній практиці. Можливо, ми побачимо набагато більше цих агентів на наших полицях для використання в хірургії. Необхідно обирати відповідні агенти для кожної конкретної ситуації в залежності від ефективності, ускладнень та ціни. 


\section{СПИСОК ВИКОРИСТАНОÏ ЛІТЕРАТУРИ}

1. Fast Stats. Inpatient surgery. Centers for Disease Control and Prevention. 2013. Retrieved from: http://www.cdc. gov/nchs/fastats/insurg.htm.

2. Spotnitz, W. D. (2012). Hemostats, sealants, and adhesives: a practical guide for the surgeon. The American Journal of Surgery, 78,1305-1321. PMID: 23265118

3. Minato, N., Katayama, Y., Yunoki, J., Kawasaki, H., \& Satou, H. (2009). Hemostatic effectiveness of a new application method for fibrin glue, the "rub-and-spray method", in emergency aortic surgery for acute aortic dissection. Ann Thorac Annals of Thoracic and Cardiovascular Surgery, 15, 265-271. PMID: 19763062

4. Go, P., Goodman, G. R., Breun, E. W., \& Hunter, J. G. (1991). The argon beam coagulator provides rapid hemostasis of experimental hepatic and splenic hemorrhage in anticoagulated dogs. The Journal of Trauma and Acute Care Surgery, 31,1294-1300. doi: 10.1097/00005373-199109000-00015

5. Samudrala, S. (2008). Topical hemostaticagentsin surgery: asurgeon'sperspective. AORN Journal, 88, S1-11. doi: 10.1016/S0001-2092(08)00586-3.

6. Woodworth, B. A., Chandra, R. K., LeBenger, J. D, Ilie B.,\& Schlosser R. J. (2009) A gelatin-thrombin matrix for hemostasis after endoscopic sinus surgery Am J Otolaryngol, 30(1), 49-53. doi: 10.1016/j.amjoto.2007.11.008.

7. Galanakis, I., Vasdev, N., \& Soomro, N. (2011). A review of current hemostatic agents and tissue sealants used in laparoscopic partial nephrectomy. Reviews in Urology, 13, 131-138. PMID: 22110396

8. Reuthebuch, O., Lachat, M. L., Vogt, P., Schurr, U., Turina, M. (2000). FloSeal: a new hemostyptic agent in peripheral vascular surgery. Vasa, 29, 204-206. doi: 10.1024/0301-1526.29.3.

9. Nasso, G., Piancone, F., Bonifazi, R., Romano, V., Visicchio, G., De Filippo, C. M., ... Speziale, G. (2009). Prospective, randomized clinical trial of the FloSea matrix sealant in cardiac surgery. The Annals of Thoracic Surgery, 88,1520-1526. doi: 10.1016/j.athoracsur.2009.07.014

10. Oz, M. C., Cosgrove, D. M., Badduke, B. R., Hill, J. D., Flannery, M. R., Palumbo, R., \& Topic, N. (2000). Controlled clinical trial of a novel hemostatic agent in cardiac surgery. The Fusion Matrix Study Group. The Annals of Thoracic Surgery, 69,1376-1382. doi: 10.1016/s0003-4975(00)01194-2

11. Achneck, H. E., Sileshi, B., Jamiolkowski, R. M., Albala, D. M., Shapiro, M. L., \& Lawson, J. H. (2010). A comprehensive review of topical hemostatic agents. The Annals of Surgery, 251, 217-228. doi: 10.1097/SLA.0b013e3181c3bcca.

12. Jackson, M. R. (2001). Fibrin sealants in surgical practice: an overview. The American Journal of Surgery, 182, 1S-7S. doi: 10.1016/s0002-9610(01)00770-x.

13. Spotnitz, W. D., \& Prabhu, R. (2005). Fibrin sealant: tissue adhesive review and update. Journal of Long-Term Effects of Medical Implants, 15, 245-270. doi: 10.1615/jlongtermeffmedimplants.v15.i3.20

14. Rousou, J. A. (2013). Use of fibrin sealants in cardiovascular surgery: a systematic review. The Journal of Cardiovascular Surgery, 28, 238-247. doi: $10.1111 /$ jocs. 12099

15. Cohen, D. M., Norberto, J., Cartabuke, R., \& Ryu, G. (1999). Severe anaphylactic reaction after primary exposure to aprotinin. The Annals of Thoracic Surgery, 67, 837-838. doi: 10.1016/s0003-4975(99)00002-8.

16. Kaul, P. (2011). Spontaneous retrograde dissection of ascending aorta from descending thoracic doi: $10.1177 / 0267659110395804$

17. Lowe, J., Luber, J., Levitsky, S., Hantak, E., Montgomery, J., Schiestl, N., Marra, S. (2007). Evaluation of the topical hemostatic efficacy and safety of TISSEEL VH S/D fibrin sealant compared with currently licensed TISSEEL VH in patients undergoing cardiac surgery: a phase 3 , randomized, double-blind clinical study. The Journal of Cardiovascular Surgery, 48, 323-331. PMID: 17505437.

18. Christenson, J. T., \& Kalangos, A. (2004). Autologous fibrin glue reinforced by platelets in surgery of ascending aorta. The Journal of Thoracic and Cardiovascular Surgery, 52, 225-229. doi: 10.1055/s-2004-821078.

19. Stark, J., \& de Leval, M. (1984). Experience with fibrin seal (Tisseel) in operations for congenital heart defects. The Annals of Thoracic Surgery, 38, 411-413. PMID: 6207785.

20. Saha, S., Muluk, S., Schenk, W., Dennis, J. W., Ploder, B., Grigorian, A., Goppelt, A. (2012). A prospective randomized study comparing fibrin sealant to manual compression for the treatment of suture hole bleeding in expanded polytetrafluoroethylene grafts. Journal of Vascular Surgery, 56, 134-141. doi: 10.1016/j.jvs.2012.01.009.

21. Malarkey, M., Epstein, J. (2010). Approval Letter TachoSil. U.S. Food and Drug Administration. Retrieved from http://www.fda.gov/Biologics BloodVaccines/BloodBlood Products/Approved Products/LicensedProductsBLAs/FractionatedPlasmaProducts/ucm207486.

22. Berdajs, D. Bürki, M., Michelis, A., \& von Segesser, L.K. (2010). Seal properties of TachoSil ${ }^{\oplus}$ : in vitro hemodynamic measurements. Interactive CardioVascular and Thoracic Surgery, 10, 910-913. doi: 10.1510/icvts.2010.235127.

23. Maisano, F., Kjærgrd, H. K., Bauernschmitt, R., Pavie, A., Rábago, G. Laskar, M., \& Falk, V. (2009). TachoSil surgical patch versus conventional haemostatic fleece material for control of bleeding in cardiovascular surgery: a randomised controlled trial. European Journal of Cardio-Thoracic Surgery, 36, 708-714. doi: 10.1016/j.ejcts.2009.04.057.

24. Pocar, M., Passolunghi, D., Bregasi, A., \& Donatelli, F. (2012). TachoSil ${ }^{\varpi}$ for postinfarction ventricular free wall rupture. Interactive CardioVascular and Thoracic Surgery, 14, 866-867. doi: 10.1093/icvts/ivs085.

25. Kuschel, T. J., Gruszka, A., Hermanns-Sachweh, B., Elyakoubi, J., Sachweh, J. S., Vázquez-Jiménez, J. F., \& Schnoering, H. (2013). Prevention of postoperative pericardial adhesions with TachoSil. The Annals of Thoracic Surgery, 95, 183-188. doi.10.1016/j.athoracsur.2012.08.057.

26. Safety and efficacy study of fibrin sealant Grifols evaluated as an adjunct to Hemostasis. Retrieved from: http://www.clinicaltrials. gov/ct2/ show/results/NCT00684047? term $=$ Study+to+Evaluate+the+Safety+and+E ficacy+of+Fibrin+Sealant+Grifols+\% 28FS+Grifols\%29\&rank=1

27. Hazelaar, S., Dijkstra-Tiekstra, M. J., de Korte, D., \& de Wildt-Eggen, J. (2012). Allogeneic single-donor cryoseal produced from fresh-frozen quarantine apheresis plasma as alternative for multidonor or autologous fibrin sealants. Transfusion, 52 517-523. doi: 10.1111/j.1537-2995.2011.03315.x

28. Buchta, C., Hedrich, H. C., Macher, M., Höcker P., \& Redl, H. (2005). Biochemical characterization of autologous fibrin sealants produced by CryoSeal and Vivostat in comparison to the homologous fibrin sealant product Tissucol/Tisseel. Biomaterials, 26(31), 6233-6241. doi: 10.1016/j.biomaterials.2005.04.014.

29. Medical Devices. CoSeal ${ }^{\oplus}$ Surgical Sealant - P010022. U. S. Food and Drug Administration. Retrieved from: http:// www.fda.gov/Medical
Devices/ ProductsandMedicalProcedures/DeviceApprovalsandClearances/RecentlyApprovedDevices/ucm083959.htm

30. Hill, A., Estridge, T. D., Maroney, M., Monnet, E., Egbert, B., Cruise, G., \& Coker G.T. (2001). Treatment of suture line bleeding with a novel synthetic surgical sealant in a canine iliac PTFE graft model. Journal of Biomedical Materials Research, 58, 308-312. doi: 10.1002/1097-4636(2001)58:3<308::aid-jbm1022>3.0.co;2-p.

31. Natour, E., Suedkamp, M., \& Dapunt, O. (2012). Assessment of the effect on blood loss and transfusion requirements when adding a polyethylene glycol sealant to the anastomotic closure of aortic procedures: a case - control analysis of 102 patients undergoing bentall procedures. Journal of Cardiothoracic Surgery, 7 , 105. doi: 10.1186/1749-8090-7-105.

32. Napoleone, C. P., Oppido, G., Angeli, E., \& Gargiulo, G. (2007). Resternotomy in pediatric cardiac surgery: coSeal ${ }^{\oplus}$ initial experience. Interactive CardioVascular and Thoracic Surgery, 6, 21-23. doi: 10.1510/icvts.2006.141531.

33. Nishimura, K., Kimura T., \& Morita, A. (2012). Watertight dural closure constructed with DuraSeal ${ }^{\mathrm{TM}}$ for bypass surgery. Neurologia medico-chirurgica(Tokyo), 52, 521-524. doi: 10.2176/nmc.52.521.

34. Newswire, P. R. (2013). DuraSeal ${ }^{\boxplus}$ sealant receives CE mark for vascular applications. Retrieved from: http://www prnewswire com/news-releases/durasealrsealant-receives-ce-mark- for-vascular-applications-55139392.html

35. Waltham, M. A. (2013). DuraSeal sealant CE mark for thoracic applications. Adhesives and Sealants.com. Retrieved from: http://www. adhesivesandsealants.com/doc/durasealr- sealant-ce-mark-for-thoracic-applic-0001.

36. Klijian, A. (2012). A novel approach to control air leaks in complex lung surgery: a retrospective review. Journal of Cardiothoracic Surgery, 7, 49. doi: $10.1186 / 1749-8090-7-49$

37. Labenz, J., \& Borsch, G. (1992). Bleeding and gastric duodenal varicdose veins: endoscopic embolisation using tissue adhesives. Deutsche Medizinische Wochenschrift, 117, 1274-1277. doi: 10.1055/s-2008-1062441.

38. Almeida, J.I., Min, R. J., Raabe, R., McLean, D. J., \& Madsen, M. (2011). Cyanoacrylate adhesive for the closure of truncal veins: 60-day swine model results. Vascular and Endovascular Surgery, 45, 631-635 doi: 10.1177/1538574411413938.

39. Hewitt, C. W., Marra, S.W., Kann, B. R., Tran H. S., Puc M. M., Chrzanowski, F. A. Jr., Tran, J. L., .. DelRossi, A. J. (2001). BioGlue surgical adhesive for thoracic aortic repair during coagulopathy: efficacy and histopathology. The Annals of Thoracic Surgery, 71, 1609-1612. doi: 10.1016/s0003-4975(01)02424-9.

40. Leva, C., Bruno, P. G., Gallorini, C., Lazzarini, I., Musazzi, G., Vittonati, L., Rizzo, L., \& Di Credico, G. (2006). Complete myocardial revascularization and sutureless $L$. technique for left ventricular free wall rupture: clinical and echocardiographic results. Interactive CardioVascular and Thoracic Surgery, 5, 408-412. doi: $10.1510 /$ icvts.2006.131037.

41. Passage, J., Jalali, H., Tam, R. K., Harrocks, S., \& O’Brien, M. F. (2002). BioGlue surgical adhesive an appraisal of its indications in cardiac surgery. The Annals of Thoracic Surgery, 74, 432-437. doi: 10.1016/s0003-4975(02)03689-5.

42. Elefteriades, J. A. (2009). How i do it: utilization of high-pressure sealants in aortic construction. Journal of Cardiothoracic Surgery, 4, 27. doi: 10.1186/1749-8090-4-27.

43. Modi, A., Bull, R., Tsang, G., \& Kaarne, M. (2011). Ostial left coronary stenosis following aortic root reconstruction with BioGlue. Interactive CardioVascular and Thoracic Surgery, 13, 243-245. doi: 10.1510/icvts.2011.273094.

44. LeMaire, S. A., Schmittling, Z. C., Coselli, J. S., Undar, A, Deady, B. A., Clubb, F. J. Jr., \& Fraser, C. D. Jr. (2002). Bioglue surgical adhesive impairs aortic growth and causes anastomotic strictures. The Annals of Thoracic Surgery, 73, 1500-1506. doi: $10.1016 / \mathrm{s} 0003-4975(02) 03512-9$

45. Sun, J. C., Whitlock, R., Cheng, J., Eikelboom, J. W., Thabane, L., Crowther, M. A., Teoh, K. H. (2008). The effect of pre-operative aspirin on bleeding, transfusion, myocardial infarction, and mortality in coronary artery bypass surgery: a systematic review of randomized and observational studies. European Heart Journal, 29, 25922600. doi: 10.1093/eurheartj/ehn104

46. Herman, C. R., Buth, K. J., Kent, B. A., Hirsch, G. M. (2010). Clopidogrel increases blood transfusion and hemorrhagic complications in patients undergoing cardiac surgery. The Annals of Thoracic Surgery, 89, 397-402. doi: 10.1016/j. athoracsur.2009.10.051. 47. Rodgers, G. M. (2011). Immune-mediated coagulopathy associated with topical bovine thrombin: review of the pediatric literature. Journal of Pediatric Hematology/Oncology, 33, 86-88. doi: 10.1097/MPH.0b013e3181ff0e43.

48. USF Hemostasis: usage of HemCon for femoral hemostasis after percutaneous procedures (USF-Hemostasis). Retrieved from: http://clinicaltrials.gov/show/ NCT00716365.

\section{Сравнение гемостатических средств, используемых в хирургии}

\section{А.В. Лукашенко, М.А. Виноградова}

Национальный институт рака, Киев

Резюме. Эффективный контроль кровотечения для достижения гемостаза при хирургических процедурах имеет важное значение для достижения положительных результатов. Когда хирург достигает быстрого гемостаза, потенциальными преимуществами является сокращение времени операции, снижение потребности в трансфузии, лучшее сопровождение пациентов на антикоагулянтной терапии, ускорение заживления послеоперационных ран и общее облегчение реабилитационного периода. Использование гемостатических агентов, герметиков и клеев улучшает гемостаз и дает ряд преимуществ во время хирургического вмешательства. За последнее время был разработан широкий спектр хирургических гемостатических агентов для использования в хирургии. Эти агенты значительно различаются по механизму действия, составу, удобству, возможности использования на влажной или сухой ткани, иммуногенности и цене. Многочисленные формулы этих агентов имеют потенциал для точного соответ- 


\section{Актуально / Topical}

ствия конкретным хирургическим потребностям. Необходимо выбирать соответствующие агенты для каждой конкретной ситуации в зависимости от эффективности, осложнений и цены.

Ключевые слова: крупный рогатый скот; фибрин; фибриноген; гемостаз; герметик; тромбин; хирургия.

\section{Comparison of hemostatic agents used in surgery}

\section{A. Lukashenko, M. Vinohradova}

National cancer institute, Kyiv

Resume. Effective management of bleeding for the achievement of hemostasis during surgical procedures is important for the achievement of positive results. When surgeons achieve rapid hemostasis, potential benefit include better visualization of surgical area, shorter operative times, decreased requirement for transfusion, better management of an anticoagulated patient, decreased wound healing time and overall improvement in patient recovery time. The use of hemostatic agents, sealants and adhesives improves hemostasis and provides a number of benefits for surgery. Recently, a wide range of surgical hemostatic agents have been developed for use in surgery. These agents vary widely in mechanism of action, composition, ease of use, adhesion to wet or dry tissue, immunogenicity and price. Numerous formulas of these agents have the potential to accurately meet specific surgical needs. You need to choose the right agents for each situation depending on the effectiveness, complications and cost.

Key words: bovine; fibrin; fibrinogen; hemostasis; sealant; thrombin; surgery. 